\title{
Oestrus detection in dairy cows based on serial measurements using univariate and multivariate analysis
}

\author{
Dedicated to Prof. Dr. agr. habil. Dr. h. c. mult. Georg Schönmuth on the occasion of \\ his $75^{\text {th }}$ birthday
}

\section{Summary}

As visual oestrus detection is difficult to perform in large herds, different technical devices were developed to facilitate oestrus detection. In this investigation the significance of the traits activity, milk yield, milk flow rate and electrical conductivity due to oestrus was analysed. The traits were recorded automatically during each milking on a commercial dairy farm. Oestrus detection was performed for 862 cows on basis of time series consisting of 15 days before oestrus, the day of oestrus and 15 days after oestrus. The day of oestrus was determined by the insemination which caused a calving after 265 to 295 days.

The univariate analyses of traits were performed by the time series methods day-to-day comparison, moving average, exponential smoothing and Box-Jenkins three parameter smoothing. For multivariate analyses a fuzzy logic model was developed and modified for the different combinations of traits. The efficiency of the detection models and traits was determined by the parameters sensitivity, specificity and error rate.

A moving average was the best suited time series method for oestrus detection by activity data. Sensitivity ranged between 94.2 and $71 \%$ and error rate was between 53.2 and $21.5 \%$ for threshold values between 40 and $120 \%$. The traits milk yield, milk flow rate and electrical conductivity were not suitable for univariate oestrus detection. Depending on the considered traits multivariate analyses resulted in sensitivities between 87.0 and 87.9\%. The error rate varied between 28.2 and $31.0 \%$. Further analyses should include previous information such as time since last oestrus.

Key Words: activity, oestrus detection, time series, fuzzy logic, multivariate analyses

\section{Zusammenfassung}

Titel der Arbeit: Brunsterkennung bei Milchkühen auf Basis serieller Messungen mit uni- und multivariaten Methoden

Das Ziel der vorliegenden Untersuchung bestand darin, die Brunsterkennung bei Milchkühen auf Basis seriell anfallender Beobachtungen zu optimieren. Für die Untersuchung standen die Brunstereignisse (Tag der Besamung) von 862 Kühen eines Milchbetriebes zur Verfügung. Als Informationsmerkmale wurden die Parameter Aktivität, Milchmenge, Leitfähigkeit und durchschnittliches Minutengemelk aus einem Management-Informations-Systems genutzt, für die ein Tageswert berechnet wurde. Die Brunsterkennung wurde an Zeitreihen überprüft, die sich auf eine Zeitperiode von 15 Tagen vor und nach dem relevanten Besamungstag erstrecken. Die univariate Auswertung basiert auf Verfahren der Zeitreihenanalyse (Tageswertvergleich, gleitender Durchschnitt, Exponential Smoothing, Box-Jenkins-Smoothing), während sich die multivariate Analyse auf ein Fuzzy Modell stützt. Die Modellevaluierung erfolgte mit den Parametern Sensitivität, Fehlerrate und Spezifität.

Für das Merkmal Aktivität wurden mit dem gleitenden Durchschnitt in Abhängigkeit des vorgegebenen Schwellenwertes (40 bis 120\%) Sensitivitäten von 71 bis $94.2 \%$ berechnet, die Fehlerrate schwankte zwischen 53,2 und 21,5 \%. Die Einbeziehung der Merkmale Milchleistung, Milchflussrate und elektrische Leitfähigkeit erbrachte keinen zusätzlichen Informationsgewinn. Die Sensitivität lag in einem Bereich von 87,0 \% bis 87,9 \%, während die Fehlerrate Werte zwischen 28,2 und 31,0 \% annahm. Weitere Analysen sollten zusätzliche Merkmale wie den Zeitabstand zur vorherigen Brunst berücksichtigen. 


\section{Introduction}

Under condition of milk quota systems, income in commercial dairy farms is increasingly influenced by fertility performance. Undetected and falsely detected oestrus result in missed and untimely inseminations with consequent losses of income. One replicated insemination results in costs of $76.7 €$ (HÜHN and WÄHNER, 1998). As calculated by MACK (1996), one day prolonged calving interval induces costs of 0.6 to $1.2 €$ per cow. By effective oestrus detection, positive impacts on the insemination results, on the calving intervals and on the total pregnancy rate can be realised (STUMPENHAUSEN, 2001).

Success for visual oestrus detection highly depends on frequency, duration and time of observation. MAATJE et al. (1997) reported a detection rate of $66.7 \%$ for visual observation of oestrus. On modern farms the number of cows per herdperson is high, so several sensors and technical devices were developed to support visual oestrus detection. An optimal oestrus detection system monitors the herd continuously, identifies the cows in oestrus accurately and automatically, operates for the productive lifetime of the cow, requires minimal labour and is accurate in identifying the appropriate physiologic or behavioural events that highly correlate with ovulation (SENGER, 1994). In the review of FIRK et al. (2002a) various traits for oestrus detection are presented. The authors determined, that previous investigations are difficult to compare due to varying analysing methods, varying numbers of cows and different parameters for evaluating the performance of the traits.

In this study suitability of activity, milk yield, milk flow rate and electrical conductivity for automatic oestrus detection in field data was analysed. Beside the traits activity and milk yield, which are frequently described to vary depending on the incidence of oestrus (KIDDY, 1977; LEHRER et al., 1992; KING, 1977; SECCHIARI et al., 1998), the electrical conductivity is reported to be related to the incidence of oestrus (LINZELL and PEAKER, 1975). The trait milk flow rate was considered as a parameter for reduced milkability, which is often noticed during oestrus by the milking personal.

In a first step the traits were analysed in an univariate manner by four different time series methods. In a second step the traits were analysed in a multivariate manner. The multivariate analyses of traits were realised by use of a fuzzy logic model. The strategy of fuzzy logic systems comprises, that a part of missing precision as well as vagueness and incertitude is tolerated at process of modelling (BOTHE, 1993). On this account the reasoning of the herd manager concerning the judging of oestrus alerts can be formalised by the fuzzy logic model.

\section{Data}

\section{Material and Methods}

Collection of data was performed on a commercial dairy farm in Brandenburg, Germany from February to December 1998. The cows were housed in 15 groups of 120 in free stall barns with concrete floors and were fed TMR ad libitum. The nutritional parameters of the rations were similar among the herds. Milking took place in a rotary milking parlour principally twice daily. Around $30 \%$ of observations originated from thrice daily milked cows. These were cows in early lactation or cows with high milk yield. During the observation period 1,090,031 observations of activity, 
milk yield, milk flow rate and electrical conductivity from 2422 Holstein Friesian cows were accumulated.

Activity was measured by a pedometer, which was attached at the left foreleg of each cow. The measurement unit of the pedometer was a mercury switch. By movement of the cow leg, the mercury oscillated between two contacts. The number of contacts were recorded at the entrance of the milking parlour and sent to the herd management computer. Milk yield, milk flow rate and electrical conductivity were recorded at each milking in the milking parlour.

Activity was calculated out of the differences between two successive pedometer readings referred to the period of time between these readings. For diluting differences concerning different levels of milk yield, the traits milk flow rate and electrical conductivity were weighted by the corresponding milk yield.

The day of oestrus was determined by an insemination, which was followed by a calving after 265 to 295 days. This insemination was the only date on which the cow was with certainty in oestrus. Therefore this date was used as reference date. For oestrus detection, time series consisting of 15 days before oestrus, the day of oestrus and 15 days after oestrus were analysed. The selected period of 15 days before oestrus resulted from the knowledge, that the duration of a mean oestrus cycle is 21 days, with a variation from 18 to 23 days (SAMBRAUS, 1978). Accordingly, in this period no additional oestrus cases were expected. A sufficient long period before oestrus is important for calculation of a steady mean by the forecasting methods.

The number of cows with complete time series for the different traits are presented in Table 1.

Table 1

Number of cows with complete time series, number of milkings, mean values $(\bar{x})$ and standard deviations (s) for the traits activity, milk yield, milk flow rate and electrical conductivity (Anzahl der Kühe mit vollständiger Zeitreihe, Anzahl der Gemelke, Mittelwert und Standardabweichung für die Merkmale Aktivität, Milchleistung, Milchfluss und elektrische Leitfähigkeit)

\begin{tabular}{lcccrr}
\hline \multicolumn{1}{c}{ Trait } & Unit & $\begin{array}{c}\text { Number of } \\
\text { analysed cows }\end{array}$ & $\begin{array}{c}\text { Number of } \\
\text { milkings }\end{array}$ & $\bar{x}$ & $\mathrm{~s}$ \\
\hline Activity & connections/h & 862 & 54740 & 4.4 & 2.9 \\
Milk yield & $\mathrm{kg}$ & 838 & 54503 & 13.1 & 2.2 \\
Milk flow rate & $\mathrm{kg} / \mathrm{min}$ & 663 & 41895 & 2.2 & 0.5 \\
Electrical conductivity & $\mathrm{mS} / \mathrm{cm}$ & 836 & 54416 & 493.8 & 50.6 \\
\hline
\end{tabular}

The main reduction of the dataset was caused, because cows without oestrus during the observation period were not considered for oestrus analyses. This were cows in the first part of lactation and cows which were already pregnant. A further, but smaller reduction resulted from missing values due to management problems.

In a first preliminary investigation the significance of the parameters error rate and specificity due to the number of false positive oestrus warnings was analysed. Error rate and specificity were calculated for different sized datasets of the trait activity. Dataset "a" consisted of 15 days before oestrus and the day of oestrus and dataset "b" consisted of an additional 15 days after oestrus. A moving average with a history of 10 values was used as forecasting method.

A second preliminary investigation examined whether the activity based on milkings or on the day resulted in different results for oestrus detection. 


\section{Methods}

Parameters for evaluation of traits and methods

For automatic oestrus detection, the relative deviation between actual observation and by time series method estimated value was calculated. If the relative deviation exceeded a threshold value varied between 40 and $120 \%$ for the trait activity and a threshold value between 3 and 14\% for the traits milk yield, milk flow rate and electrical conductivity, the cow was reported as in oestrus. The concerning observation would be classified as true positive, if the threshold was exceeded on the day of oestrus or one day earlier and false positive on any other day. If the relative deviation was below the threshold value on the day of oestrus, the concerning observation was classified as false negative. Correctly not detected oestrus were identified as true negative observations.

Accuracy of oestrus detection by time series methods and the fuzzy logic model was expressed by sensitivity and error rate. Sensitivity represents the percentage of correctly detected oestrus of all oestrus.

Sensitivity $=\frac{\text { true positive }}{\text { true positive }+ \text { false negative }} * 100$

The error rate indicates the percentage of cows which are not in oestrus, but exceed the threshold value.

$$
\text { Error rate }=\frac{\text { false positive }}{\text { false positive }+ \text { true positive }} * 100
$$

The parameter specificity was used for evaluation of oestrus detection results in other investigations (KOELSCH et al., 1994; DE MOL, 2000; MELE et al., 2001). For a better comparability the specificity was also considered as a parameter for evaluating the accuracy of the methods and the traits. The specificity represents the percentage of correctly not detected oestrus outside oestrus periods.

Specificity $=\frac{\text { true negative }}{\text { true negative }+ \text { false positive }} * 100$

\section{Univariate analyses}

The automatic analysing of single data was realised by application of a day-to-day comparison, a moving average, an exponential smoothing and a Box-Jenkins three parameter smoothing. The selection of methods for univariate analyses was realised according to previous applied time series methods for oestrus or mastitis detection (ARNEY, et al., 1994; YANG, 1998; SECCHIARI et al., 1999). The Box-Jenkins three parameter smoothing was selected because MAKRIDAKIS and WHEELWRIGHT (1978) described this method as suitable for stationary and non stationary data.

The purpose of time series methods is to calculate a forecast value $\left(\hat{Y}_{N+1}\right)$ on basis of previous observation values $\left(\mathrm{Y}_{\mathrm{N}}\right)$. By use of a day-to-day comparison the current measurement is compared with the measurement of the previous milking or day, respectively.

$\hat{Y}_{N+1}=Y_{N}$ 
The comparison value of a moving average consists of a running mean out of a defined amount of previous observations of the same cow (MOTTRAM, 1997).

$\hat{Y}_{N+1}=\sum_{\mathrm{t}=1}^{\mathrm{N}} \mathrm{Y}_{\mathrm{t}} / N$

The smoothing effect of the moving average increases with the increasing number of considered observations in history. Analyses for all traits were performed with 5 and 10 values in history, respectively. Observation values, which caused an exceeding of the threshold value were not considered as history values in the moving average. Instead, a moving average of the previous observations was used for further forecasting.

The exponential smoothing represents a special form of a moving average. Different weights can be given to previous observations (MAKRIDAKIS and WHEELWRIGHT, 1978).

$\hat{Y}_{N+1}=\sum_{t=0}^{N} \alpha \cdot(1-\alpha)^{\mathrm{t}} \cdot \mathrm{Y}_{\mathrm{N}-\mathrm{t}}$

with $\alpha=0.2,0.4,0.6,0.8$

The chosen $\alpha$-value decreases exponentially with increasing distance between history value and actual observation, for high $\alpha$-values stronger than for low $\alpha$-values. Observation values, which caused an exceeding of the threshold value, were not considered as history values in the exponential smoothing. Instead, a moving average of the previous observations was used as input value for further forecasting. Analyses for all traits were performed with 5 and 10 values in history, respectively.

The forecasting value of a Box-Jenkins three parameter smoothing is calculated by adding $\theta_{\mathrm{a}}, \theta_{\mathrm{b}}$, and $\theta_{\mathrm{c}}$ weighted deviations between previous observation and estimated value to the last observation value.

$$
\hat{Y}_{N+1}=\mathrm{Y}_{\mathrm{N}}+\theta_{\mathrm{a}} \cdot\left(\mathrm{e}_{\mathrm{N}}-\mathrm{e}_{\mathrm{N}-1}\right)+\theta_{\mathrm{b}} \cdot \mathrm{e}_{\mathrm{N}}+\theta_{\mathrm{c}} \cdot \sum_{\mathrm{N}=\mathrm{t}}^{\mathrm{t}-9} \mathrm{e}_{\mathrm{N}} \quad \text { with }-1 \leq \theta_{\mathrm{a}}, \theta_{\mathrm{b}}, \theta_{\mathrm{c}} \leq 1
$$

The $\theta$-values varied in 0.2 steps between -1 and 1 . The combination of $\theta$-values with the lowest mean square error was selected as forecasting value.

Because of non-existence of a forecast value in the first period, the first observation was used as first forecast in the day-to-day comparison and in the Box-Jenkins three parameter smoothing. Forecasting of the moving average and the exponential smoothing was started as soon as two observations were available.

Multivariate analyses

An improvement of the oestrus detection results was expected by multivariate analyses of the traits. The combination of traits was realised by fuzzy logic. The fuzzy logic models for different combinations of activity, milk yield, milk flow rate and electrical conductivity were developed with MATLAB software (MATLAB, 2000). Preparation of data for calculation with Matlab and computation of sensitivity and error rate were performed by using SAS (1998).

Fuzzy logic is a well known method for application in controlling, decision support systems and classification (GRAUEL, 1995). The advantages of a fuzzy logic model are, that the model is easy to interpret and easy to adapt by changing the membership 
functions and the rules not necessarily by a modelling expert (DE MOL and WOLDT, 2001). In contrast to common sets, where each element belongs to a set or not, fuzzy sets have a range of membership between 0 and 1 . Each element can belong to special degrees to several sets (ALTROCK, 1995).

The three elements of a fuzzy logic model are the fuzzification, the inference and the defuzzification. Input and output values are crisp. Fuzzy sets are only applied inside the fuzzy logic model for calculation.

\section{Fuzzification}

Input values for fuzzification were the relative deviations between estimated and observed values. The estimation value was calculated by the best suited time series method for each trait. The input values are transformed into fuzzy values by the linguistic interpretation through membership functions and the grade of membership. The superior area of each membership function showed grades of membership of 1 and the lower areas of membership function showed grades of membership of 0 . Intermediate areas of the membership functions showed gradual grades of membership between 0 and 1 . The range of relative deviation was represented for each trait by three membership functions, indicating a low, normal and high level of relative deviation. The optimal shape of the membership functions was developed after univariate calculation of each trait in the fuzzy logic model, with regard to the optimal number of correct oestrus identification. Figure 1 illustrates the shapes of utilised membership functions for the trait activity.

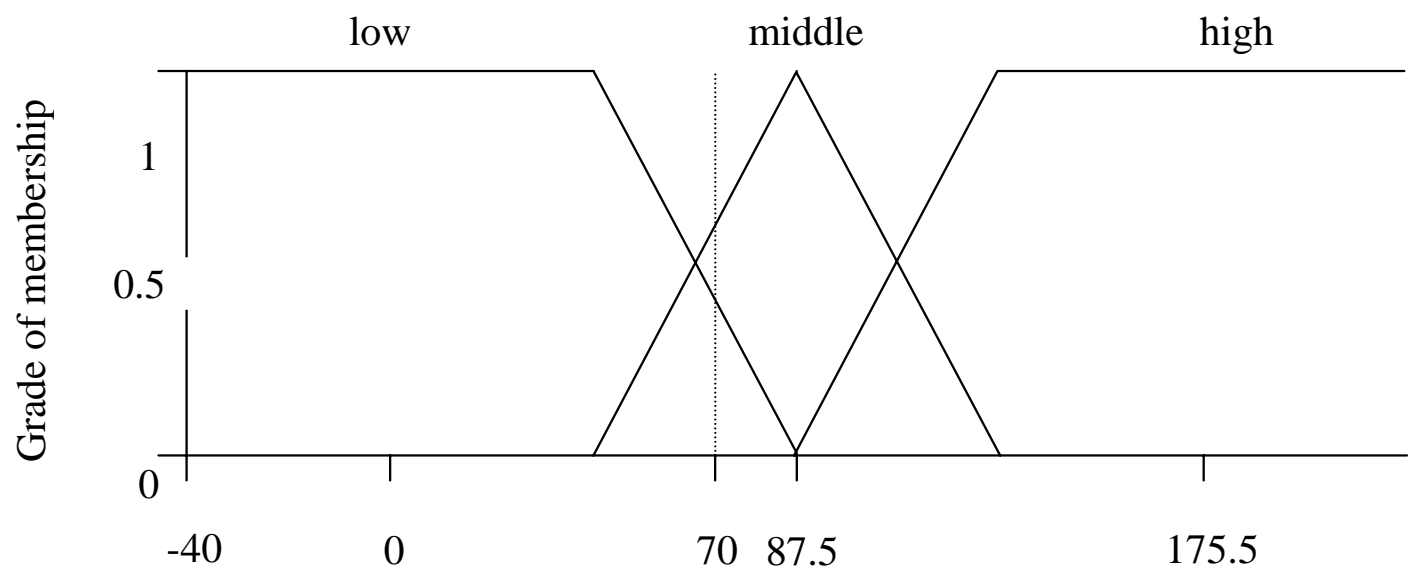

Relative deviation between measured and estimated value

Fig. 1: Membership functions for the trait activity (Zugehörigkeitsfunktionen für das Merkmal Aktivität)

A relative deviation between measured and estimated value of $70 \%$ would result in intersections with the membership functions "low" and "middle". The grades of membership for the membership functions "low" and "middle" would be 0.4 and 0.6, respectively. The grade of membership for the membership function "high" would be 0 . The range of the membership functions for all traits are presented in Table 2. The first value in brackets indicates the relative deviation of each trait and the second value presents the corresponding grade of membership. These points of characterisation are linked by straight lines. The intersected membership functions and the corresponding grades of membership represented the input values for the fuzzy inference. 
Table 2

Utilised membership functions for the traits activity, milk yield, milk flow rate and electrical conductivity (Zugehörigkeitsfunktionen für die Merkmale Aktivität, Milchleistung, Milchflussrate und elektrische Leitfähigkeit).

\begin{tabular}{|c|c|c|c|c|c|c|c|}
\hline Trait & Name of & & & Points of $\mathrm{C}$ & acterisatiol & & \\
\hline Activity & $\begin{array}{l}\text { low } \\
\text { middle } \\
\text { high }\end{array}$ & $\begin{array}{l}(-40 ; 1) \\
(-40 ; 0) \\
(-40 ; 0)\end{array}$ & $\begin{array}{l}(37.5 ; 1) \\
(37.5 ; 0) \\
(87.5 ; 0)\end{array}$ & $\begin{array}{c}(87.5 ; 0) \\
(87.5 ; 1) \\
(137.5 ; 1)\end{array}$ & $\begin{array}{c}(200 ; 0) \\
(137.5 ; 0) \\
(200 ; 1)\end{array}$ & $(200 ; 0)$ & \\
\hline Milk yield & $\begin{array}{l}\text { low } \\
\text { normal } \\
\text { high }\end{array}$ & $\begin{array}{l}(-20 ; 1) \\
(-20 ; 0) \\
(-20 ; 0)\end{array}$ & $\begin{array}{l}(-10 ; 1) \\
(-10 ; 0) \\
(7.5 ; 0)\end{array}$ & $\begin{array}{c}(-5 ; 0) \\
(-5 ; 1) \\
(12.5 ; 1)\end{array}$ & $\begin{array}{c}(20 ; 0) \\
(7.5 ; 1) \\
(20 ; 1)\end{array}$ & $(12.5 ; 0)$ & $(20 ; 0)$ \\
\hline Milk flow rate & $\begin{array}{l}\text { low } \\
\text { middle } \\
\text { high }\end{array}$ & $\begin{array}{l}(-20 ; 1) \\
(-20 ; 0) \\
(-20 ; 0)\end{array}$ & $\begin{array}{l}(35 ; 1) \\
(35 ; 0) \\
(40 ; 0)\end{array}$ & $\begin{array}{l}(40 ; 0) \\
(40 ; 1) \\
(45 ; 1)\end{array}$ & $\begin{array}{l}(60 ; 0) \\
(45 ; 0) \\
(60 ; 1)\end{array}$ & $(60 ; 0)$ & \\
\hline $\begin{array}{l}\text { Electrical } \\
\text { conductivity }\end{array}$ & $\begin{array}{l}\text { low } \\
\text { high } \\
\text { higher }\end{array}$ & $\begin{array}{l}(0 ; 1) \\
(0 ; 0) \\
(0 ; 0)\end{array}$ & $\begin{array}{l}(10 ; 1) \\
(10 ; 0) \\
(14 ; 0)\end{array}$ & $\begin{array}{l}(14 ; 0) \\
(14 ; 1) \\
(18 ; 1)\end{array}$ & $\begin{array}{l}(20 ; 0) \\
(18 ; 0) \\
(20 ; 1)\end{array}$ & $(20 ; 0)$ & \\
\hline
\end{tabular}

\section{Fuzzy inference}

The linguistic combination of the traits was performed in the fuzzy inference. The utilised rules result from human knowledge and have the form: if condition, then conclusion. The conditions were represented by the intersected membership functions and the corresponding grades of membership of the traits activity, milk yield, milk flow rate and electrical conductivity, respectively. The conclusion of combined traits was in this investigation the determination of the status of the cow, with the membership functions oestrus and no oestrus. In Table 3 an example for a rule box for combination of the traits activity and milk flow rate is presented: if activity is middle and milk flow rate is low, then the cow is in oestrus. In each conclusion, two grades of membership, each originating from the intersection points with the input value of one trait must been considered. By application of the fuzzy operators Max and Min, a reduction to one grade of membership per conclusion is reached. The Min and Max operators represent generalisations of the boolean "and" and "or", respectively. The reduced grades of membership present the input values for the third step of the fuzzy model, the defuzzification.

Table 3

An example for rules for the fuzzy inference for the traits activity and milk flow rate (Fuzzy Inference für die Merkmale Aktivität und Milchleistung)

\begin{tabular}{lllcc}
\hline & & & Activity & high \\
\hline Milk flow & low & low & Middle & oestrus \\
rate & middle & no oestrus & Oestrus & oestrus \\
& high & no oestrus & no oestrus & oestrus \\
\hline
\end{tabular}

\section{Defuzzification}

By defuzzification, fuzzy values were transformed back into crisp results. The output variable oestrus was subdivided into the membership functions: "no oestrus" and 
“oestrus". The grades of membership, calculated in the fuzzification step and rules of inference result in special areas below the membership functions $\left(\mu_{B}\right)$ of the output variable status of the cow. By calculation of the centre of gravity of these areas, the fuzzy values are transformed back to one crisp value. The resulting value $\mathrm{x}_{0}$ represented the result of defuzzification (BOTHE, 1993). Values higher than 0.5 were treated as oestrus alerts. Fuzzy logic models were developed for all possible combinations of the trait activity with the traits milk yield, milk flow rate and electrical conductivity.

\section{Results}

\section{Evaluation of parameters}

Accuracy and reliability are the most important criteria for evaluation of the performance of an oestrus detection model. Accuracy is commonly denoted by the parameter sensitivity. The parameters specificity and error rate were applied for the evaluation of the reliability of an oestrus detection model. The significance of the parameters specificity and error rate was investigated on basis of two different sized datasets. The forecasting was performed by a moving average with a history of 10 values (Table 4). The specificity increased with increasing threshold value from 96.2 to $99.3 \%$ in dataset a and from 96.0 to $99.3 \%$ in dataset b. The reduction of false positive oestrus warnings, due to the increased threshold value was more obviously indicated by the error rate. The error rate ranged from 33.4 to $11.4 \%$ and from 53.2 to $21.5 \%$ in dataset a and b, respectively.

\section{Table 4}

Comparison between specificity and error rate for the trait activity by a moving average with a history of 10 values on basis of two different sized datasets ( $\mathrm{n}=862$ cows) (Spezifität und Fehlerrate für das Merkmal Aktivität in Abhängigkeit von der Zeitperiode)

\begin{tabular}{ccccc}
\hline $\begin{array}{c}\text { Threshold } \\
\text { (in \%) }\end{array}$ & \multicolumn{2}{c}{ Specificity (in \%) } & \multicolumn{2}{c}{ Error rate (in \%) } \\
& Dataset a & Dataset b & Dataset a & Dataset b \\
\hline 40 & 96.2 & 96.0 & 33.4 & 53.2 \\
60 & 98.3 & 98.0 & 19.1 & 36.4 \\
80 & 98.6 & 98.6 & 16.3 & 30.2 \\
100 & 99.1 & 99.1 & 12.5 & 24.1 \\
120 & 99.3 & 99.3 & 11.4 & 21.5 \\
\hline
\end{tabular}

Dataset $\mathrm{a}=15$ days before and day of oestrus $(\mathrm{n}=11443)$; Dataset $\mathrm{b}=$ dataset $\mathrm{a}+15$ days after oestrus $(\mathrm{n}=23820)$

Dataset a included nearly twice as many observations as dataset b. According to this, it is natural that the number of false positive oestrus warnings increases for dataset $b$. This fact can better be seen by application of the parameter error rate than by the parameter specificity, because the calculation of the specificity is based on the number of true negative and false positive observations and accordingly this parameter responds worse than the error rate, which is based on false and true positive observations. Therefore, in further analyses the reliability of traits and methods for oestrus detection was evaluated by the sensitivity and error rate.

\section{Evaluation of the data basis for forecasting}

The traits for oestrus detection were available on a milking basis, as the traits were recorded at each milking. Because in various investigations oestrus detection was 
performed either with data on milking basis or data on a daily basis, sensitivity and error rate were calculated for both kinds of datasets (Table 5). A moving average with a history of 10 values was used as forecasting method. For other methods of time series analyses, the results were on a comparable level. In both datasets sensitivity and error rate decreased with increasing threshold value. For threshold values of 40 and $60 \%$, sensitivities were similar for oestrus detection on a milking basis and on a daily basis. Higher threshold values resulted in larger differences between both datasets in sensitivity. If the threshold value was $120 \%$, sensitivity was $16.1 \%$ lower for oestrus detection on a daily basis than for oestrus detection on a milking basis. The error rates for oestrus detection on a daily basis ranged between 53.2 and $21.5 \%$. For oestrus detection on basis of milkings error rates were 23.2 to $11.4 \%$ higher.

Table 5

Sensitivities and error rates on basis of milkings $(\mathrm{n}=53016)$ and days $(\mathrm{n}=23820)$ for the trait activity calculated by a moving average with a history of 10 values ( $\mathrm{n}=862$ cows) (Sensitivität und Spezifität für das Merkmal Aktivität in Abhängigkeit der Bezugsbasis -Gemelk, Tageswert)

\begin{tabular}{ccccc}
\hline $\begin{array}{c}\text { Threshold } \\
\text { (in \%) }\end{array}$ & \multicolumn{2}{c}{ Sensitivity (in \%) } & \multicolumn{2}{c}{ Error rate (in \%) } \\
\hline 40 & 96.4 & 94.2 & 76.4 & Milking basis \\
60 & 94.8 & Daily basis & 53.6 & 36.2 \\
80 & 92.9 & 86.2 & 43.6 & 30.2 \\
100 & 89.7 & 79.5 & 36.9 & 24.1 \\
120 & 87.1 & 71.0 & 32.9 & 21.5 \\
\hline
\end{tabular}

The calculation of a daily value for each cow and trait caused a smoothing effect within cow. Small outliers were eliminated without effecting high outliers. Further investigations were performed with datasets on a daily basis, because of a slightly favourable relationship between sensitivity and error rate in comparison with the dataset on a milking basis. Oestrus detection on basis of the traits milk yield, milk flow rate and electrical conductivity was also performed on a daily basis. These traits showed the same characteristics of the sensitivities and error rates subject to different threshold values for the utilised databases.

\section{Univariate analyses}

The univariate analyses were performed to investigate the potential benefit of the traits activity, milk yield, milk flow rate and electrical conductivity for oestrus detection. In addition, for each trait a comparison between the time series methods day-to-day comparison, moving average, exponential smoothing and Box-Jenkins three parameter smoothing was performed. Except for the day-to day-comparison, analyses were performed with varying observations in the history of the time series methods. The optimal size of history was 10 values for analysing the trait activity. Best results for oestrus detection based on the traits milk yield, milk flow rate and electrical conductivity were reached by histories of 5 values of the time series methods. The following results are based on the optimal size of history for each time series method and trait. Results for oestrus detection by the trait activity are presented in Figure 2. 

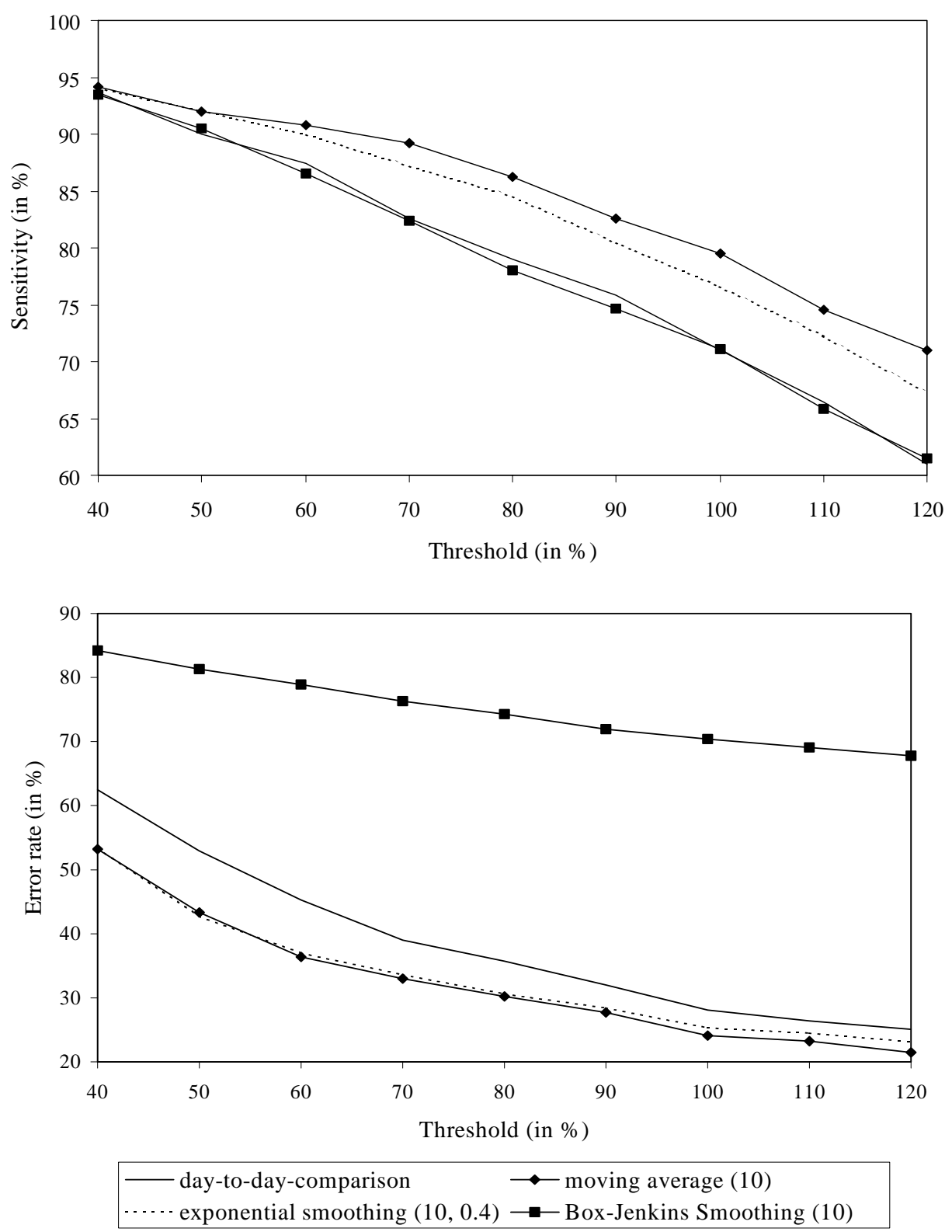

Fig. 2: Sensitivity and error rate for oestrus detection by the trait activity, depending on the threshold and on the forecasting method ( $\mathrm{n}=862$ cows) (Sensitivität und Fehlerrate für die Brunsterkennung auf Basis der Aktivität bei unterschiedlichen Methoden und Schwellenwerten)

The sensitivity decreased with increasing threshold value with a similar gradient for the analysed time series methods. Independent from the threshold value, the best results for sensitivity were reached by a moving average with 94.2 to $71 \%$. Lowest sensitivities were calculated by the day-to-day comparison and the Box-Jenkins three parameter smoothing, with sensitivities between 93.5 and $61.5 \%$.

The error rate decreases with increasing threshold value. Obvious highest error rates were found for the Box-Jenkins three parameter smoothing, with 84.2 to $67.8 \%$. Lowest error rates resulted from oestrus detection by moving average with a history of 10 values with 53.2 to $21.5 \%$. Results for the exponential smoothing with a history of 10 values and an $\alpha$-value of 0.4 were on the same level (53.4 to 23.1\%). Because of best results for sensitivity in combination with satisfying results for error rate, the 
moving average with a history of 10 values was identified as the best suited time series method for univariate oestrus detection by activity data.

For oestrus detection by the traits milk yield, milk flow rate and electrical conductivity only small differences in sensitivity and error rate between the time series methods occurred. The sensitivities and error rates were calculated by the best suited time series method for each trait (Table 6). This was an exponential smoothing with a history of 5 values and an $\alpha$-value of 0.4 for the traits electrical conductivity and milk flow rate and a day-to-day comparison for the trait milk yield.

Table 6

Sensitivities and error rates for oestrus detection by the traits electrical conductivity (836 cows), milk flow rate (663 cows) and milk yield (838 cows) depending on the threshold, calculated with the best suited time series method (Sensitivität und Fehlerrate für die Brunsterkennung auf Basis der Leitfähigkeit, Milchflußrate und Milchleistung bei unterschiedlichen Schwellenwerten)

\begin{tabular}{ccccccc}
\hline $\begin{array}{c}\text { Threshold } \\
\text { (in \%) }\end{array}$ & $\begin{array}{c}\text { Electrical } \\
\text { conductivity }^{1)}\end{array}$ & $\begin{array}{c}\text { Milk flow } \\
\text { rate }^{1)}\end{array}$ & Milk yield ${ }^{2)}$ & $\begin{array}{c}\text { Error rate (in \%) } \\
\text { Electrical }_{\text {conductivity }^{1)}}\end{array}$ & $\begin{array}{c}\text { Milk flow } \\
\text { rate }^{1)}\end{array}$ & Milk yield $^{2)}$ \\
\hline 3 & 98.6 & 99.5 & 90.7 & 96.0 & 95.6 & 95.2 \\
6 & 90.9 & 98.5 & 62.3 & 95.6 & 95.1 & 94.0 \\
10 & 52.8 & 90.2 & 31.6 & 94.2 & 93.8 & 91.7 \\
14 & 16.6 & 67.6 & 18.9 & 92.0 & 92.2 & 89.0 \\
\hline
\end{tabular}

${ }^{1)}$ Exponential smoothing, with a history of 5 values and an $\alpha$-value of $0.4 ;{ }^{2)}$ Day-to-day-comparison

Low threshold values resulted in high sensitivities for all traits. A threshold value of $10 \%$ resulted in low sensitivities for electrical conductivity and milk yield, with 52.8 and $31.6 \%$, respectively and moderate sensitivity for milk flow rate with $90.2 \%$. Independent from threshold value, the error rate was high for all traits with 96 to $89 \%$.

\section{Multivariate Analyses}

The performance of the developed fuzzy logic model was estimated by single analysis of the trait activity in the fuzzy logic model. The obtained results were used as basis for comparison of the combined processed traits. The trait activity was linked with different combinations of the traits milk yield, milk flow rate and electrical conductivity (Table 7).

Table 7

Sensitivity and error rate for different combinations of traits by fuzzy logic (Sensitivität und Fehlerrate für die Brunsterkennung in Abhängigkeit von der Merkmalskombination)

\begin{tabular}{|c|c|c|c|c|c|}
\hline Trait 1 & Trait 2 & Trait 3 & Trait 4 & $\begin{array}{l}\text { Sensitivity } \\
\text { (in \%) }\end{array}$ & $\begin{array}{c}\text { Error rate } \\
\text { (in \%) }\end{array}$ \\
\hline Activity & & & & 90.5 & 32.2 \\
\hline Activity & Milk yield & & & 87.6 & 30.1 \\
\hline Activity & Milk flow rate & & & 87.0 & 29.2 \\
\hline Activity & El. conductivity & & & 87.4 & 31.0 \\
\hline Activity & Milk yield & Milk flow rate & & 87.9 & 29.1 \\
\hline Activity & Milk yield & El. conductivity & & 87.4 & 29.7 \\
\hline Activity & Milk flow rate & El. conductivity & & 87.7 & 29.0 \\
\hline Activity & Milk yield & Milk flow rate & El. conductivity & 87.2 & 28.2 \\
\hline
\end{tabular}


For the single analysis of activity data in the fuzzy logic model, sensitivity was $90.5 \%$ and error rate was $32.2 \%$. The involvement of various traits did not improve the results for oestrus detection. Independent of the combined traits, the parameters sensitivity and error rate decreased both. The small fluctuations in sensitivity and error rate were mainly caused by varying numbers of cows in the datasets. The simultaneous consideration of all traits resulted in a sensitivity of $87.2 \%$ and an error rate of $28.2 \%$.

\section{Discussion}

The basis for the evaluation of the performance of the oestrus detection models is the knowledge of the actual status of the cows on each day of observation. The presence of oestrus can be verified as a result of collecting milk progesterone samples. This method was mainly practised in investigations with a limited number of cows (ROTH, 1987; MAATJE et al., 1997; XU et al., 1998; ERADUS et al., 1998). In larger dairy herds, the daily sampling of the cows is time-consuming and expensive. A further option to establish the status of the cows is to specify the date of insemination, which is determined by the following calving. This date can be utilised as reference, because it is the only day, where the cow certainly was in oestrus. Previous oestrus cases were not considered in order to preclude false recordings of oestrus. WENDL and KLINDTWORTH (1997) validated the oestrus cases by successful pregnancy monitoring. The disadvantage of this method is, that only one oestrus per cow and lactation is available. In the nearer future, online progesterone sensors might be available for commercial dairy farms (MOTTRAM et al., 2001; DELWICHE et al., 2001). These sensors should enable the farmer to determine the status of the cow directly after milking.

The unequivocal determination of the status of the cow on each day of lactation is a condition for the evaluation of the effectiveness and reliability of oestrus warnings. In literature, several parameters are presented for evaluating the performance of oestrus detection models (FIRK et al., 2002a). Most important for the practical farmer is the information about the number of detected oestrus on all oestrus and the quantity of falsely detected oestrus. The number of detected oestrus on all oestrus can be indicated by the parameter sensitivity. By the parameter error rate, the proportion of false detected oestrus on all oestrus warnings is expressed. The specificity defines the percentage of true negative observations outside oestrus periods. Fewer false indications of oestrus result in higher values for specificity. In comparison to the error rate, specificity varied minimally, because specificity is more influenced by the number of true negative observations than by false positive observations. Due to the high number of observations outside oestrus period compared with the number of oestrus periods, the relative significance of the parameter specificity for evaluation of the performance of oestrus detection models is low. Especially in the larger dataset 'b', specificity showed a high value, even though the number of false positive observations was higher than in dataset ' $a$ '.

DE MOL et al. (1999) pointed out, that activity and milk yield are influenced by the period between two milkings and by the daily rhythm. Accordingly, the authors calculated the hourly milk yield after each milking for each cow and performed oestrus detection on basis of milkings. Because FIRK et al. (2002b) were not able to demonstrate differences between morning and evening recordings of the trait activity, 
oestrus detection was performed on basis of milkings and on a daily basis. The comparison between both datasets resulted in a slightly favourable relationship between sensitivity and error rate for oestrus detection by daily processed data. This result was consistent with the findings from LEWIS and NEWMAN (1984). The calculation of a daily value for each cow caused a smoothing effect, by which small outliers of the trait can be eliminated. The smoothing effect showed a higher impact on the error rate than on the sensitivity. For the traits milk yield, milk flow rate and electrical conductivity a daily value was also estimated for oestrus detection because milkings were not performed in defined milking periods and beside twice daily, some cows were milked thrice daily.

In literature no comparisons between different time series methods for oestrus detection were made. Common methods for detection of oestrus and diseases in dairy cows are a day-to-day comparison (ARNEY et al., 1994), a moving average (WENDL et al., 1995) and an exponential smoothing (SECCHIARI et al., 1999). In addition to these methods, a Box-Jenkins three parameter smoothing (MAKRIDAKIS and WHEELWRIGHT, 1978) was considered in the comparison of methods for univariate analyses. Moderate differences between the analysing methods were found for results for oestrus detection by the trait activity. The sensitivity and error rate improved for all methods with increasing number of observations in history. Only small differences in effectiveness of the time series methods were found for the traits milk yield, milk flow rate and electrical conductivity. Changes in milk yield due to oestrus were detected most reliably by a day-to-day comparison. By an exponential smoothing changes in milk flow rate and electrical conductivity during oestrus were detected best.

The results from univariate analyses identify the trait activity as well qualified for oestrus detection. A threshold value of $40 \%$ resulted in a sensitivity of $94.2 \%$, indicating that most cows in oestrus were detected by the oestrus detection model. The corresponding error rate of 53.2\% was too high. Accordingly, more than every second cow was wrongly reported as in oestrus. A reduction of false positive observations was reached by application of increased threshold values. In this context sensitivity decreased as well. For a threshold value of $100 \%$, sensitivity was $79.5 \%$ and error rate was 24.1\%. MAATJE et al. (1997) calculated for the same threshold value a comparable sensitivity, with 78\%, but the corresponding error rate was higher (32\%). WENDL and KLINDTWORTH (1997) were able to detect $86 \%$ cows of all cows in oestrus, but $55 \%$ of oestrus warnings were false. Similar detection results were calculated by MELE et al. (2001). On basis of a moving average, the sensitivity was $86.6 \%$ and $48.3 \%$ of the oestrus warnings were false. An improvement in sensitivity to $87.7 \%$ and in error rate to $44 \%$ was reached by application of the tracking signal method. Due to differences in treatment of the cows, different threshold values, different parameters for evaluation and different methods for forecasting, a comparison with further investigations was difficult to perform. In addition, as pointed out by VAN ASSELDONK et al. (1998) oestrus detection rates for commercial dairy farms are commonly lower than for experimental research stations.

Oestrus detection by the traits milk yield, milk flow rate and electrical conductivity resulted in low sensitivities and high error rates. Accordingly, these traits were not suitable for oestrus detection in this dataset. As reported by SCHOFIELD (1989), milk yield and milk flow rate are not significantly affected by oestrus. Variation in these traits was more influenced by other factors than by oestrus. YANG (1998) confirmed, 
that variation in milk yield was not very pronounced. Results from LEWIS and NEWMAN (1984) emphasised that these traits have insufficient magnitude and precision for oestrus detection.

ROTH (1987) pointed out, that the single processing of one trait for oestrus detection results in a high rate of false positive oestrus warnings. The required effort for manual controlling would exceed a reasonable degree of time. The author suggested a combination of all available computer based management aids and all sensor based systems in a superior herd management program. LEHRER et al. (1992) and BREHME et al. (2001) also recommended multivariate processing of data, with the aim to reduce the number of false positive oestrus warnings and simultaneously to maintain the number of true positive alerts. Common methods for multivariate processing of data are the Kalman filter and fuzzy logic. Using a Kalman filter DE MOL et al. (1997) calculated sensitivities between 83 and 94\% and specificities between 95 and 98\% depending on the confidence interval from 95 to 99.9\%, based on changes in activity, milk temperature and milk yield. Comparable sensitivities were reached by YANG (1998) using a simple fuzzy logic model without defuzzification and a complete fuzzy logic model for analyses of the traits activity and milk yield, with 91 and 90\%, respectively. The corresponding error rates were 26 and $18 \%$. The sensitivities of the present investigation were independent of the considered traits ranged from 87.0 to $87.9 \%$. The error rates were between 28.2 and $31.0 \%$. In agreement with YANG (1998), no additional gain was obtained by multivariate analyses of the considered traits. This was expected since analyses based on yield, milk flow and conductivity were without information value.

ERADUS et al. (1998) pointed out, that for multivariate analyses a second reliable trait is essential for satisfying detection results. Most benefit is expected by considering information of previous oestrus cases in the detection model (FIRK et al., 2002c).

\section{References}

ALTROCK, C.:

Fuzzy Logic, Band 1, Technologie. R. Oldenbourg Verlag. 1995

ARNEY, D.R.; KITWOOD, S.E.; PHILLIPS, C.J.C.:

The increase in activity during oestrus in dairy cows. Appl. Anim. Behav. Sci. 40 (1994), 211-218

BREHME, U.; AHLERS, D.; LAUFELD, P.; SCHEIBL, P.; SCHERPING, E.; WERNER, D.:

Brunsterkennung und Gesundheitsüberwachung mittels sensorgestützter Funkdatenlogger. In: Bau, Technik und Umwelt in der landwirtschaftlichen Nutztierhaltung, Beiträge zur 5. Internationalen Tagung 2001, Hohenheim, 6.-7. März 2001, Hrsg.: Inst. für Agrartechnik der Universität Hohenheim, Germany. pp. 44-49. 2001
}

BOTHE, H.H.:

Fuzzy Logic - Einführung in Theorie und Anwendungen. Springer Verlag. 1993

DELWICHE, M.; TANG, X.; BONDURANT, R.; MUNRO, C.:

De MOL, R.M.:

Oestrus detection with a progesterone biosensor. Transactions of the ASAE, in press. 2001

Automated detection of oestrus and mastitis in dairy cows. Ph.D. Thesis Wageningen, The Netherlands. 2000

De MOL, R.M. ; WOLDT, W.E.:

Application of fuzzy logic in automated cow status monitoring. J. Dairy Sci. 84 (2001), 400-410

De MOL, R.M.; KEEN, A.; KROEZE, G.H.; ACHTEN, J.M.F.H.:

Description of a detection model for oestrus and diseases in dairy cattle based on time series analysis combined with a Kalman filter. Comput. Electron. Agric. 22 (1999), 171-185

De MOL, R.M.; KROEZE, G.H.; ACHTEN, J.M.F.H.; MAATJE, K.; ROSSING, W.: 
Results of a multivariate approach to automated oestrus and mastitis detection. Livest. Prod. Sci. 48 (1997), 219-227

ERADUS, W.J.; SCHOLTEN, H.; UDINK TEN CATE, A.J.:

Oestrus detection in dairy cattle using a fuzzy inference system. IFAC control applications and ergonomics in agriculture: a proceedings volume from the IFAC Workshop, Athens, Greece, 14-17 June 1998, 185-188

FIRK, R.; STAMER, E.; JUNGE, W.; KRIETER, J.:

Automation of oestrus detection in dairy cows: a review. Livest. Prod. Sci., 75 (2002a), 219-232

FIRK, R.; STAMER, E.; JUNGE, W.; KRIETER, J.:

Systematic effects on activity, milk yield, milk flow rate and electrical conductivity. Arch. Tierz., Dummerstorf 45 (2002b), 213-222

FIRK, R.; STAMER, E.; JUNGE, W.; KRIETER, J.:

Improving oestrus detedtion by combination of activity masurements with information about previous oestrus cases. Livest. Pro. Sci, in press, 2002c

GRAUEL, A.:

Fuzzy-Logic - Einführung in die Grundlagen mit Anwendungen. BI Wissenschaftsverlag, Mannheim, Leipzig, Wien, Zürich. 1995

HÜHN, U.; WÄHNER, M.:

Ökonomische Bewertung der Brunstsynchronisation bei Rind und Schwein. In: Fruchtbarkeitsmanagement bei Rind und Schwein. Hrsg. Arbeitskreis Großtierpraxis, VAV, Verl. für Agrarwiss. und Veterinärmedizin, 1998

KIDDY, C.A.:

Variation in physical activity as an indicator of oestrus in dairy cows. J. Dairy Sci. 60 (1977), 235-243.

KING, J.O.L.:

The effect of oestrus on milk production in cows. Vet. Rec. 101 (1977, 107-108

KOELSCH, R.K.; ANESHANSLEY, D.J.; BUTLER, W.R.:

Analysis of activity measurement for accurate oestrus detection in dairy cattle. J. Agric. Eng. Res. 58 (1994), 107-114

LARK, R.M.; NIELSEN, B.L.; MOTTRAM, T.T.:

A time series model of daily milk yields and its possible use for detection of a disease (ketosis). Anim. Sci. 69 (1999), 573-582

LEHRER, A.R.; LEWIS, G.S.; AIZINBUD, E.:

Oestrus detection in cattle: recent developments. Anim. Reprod. Sci. 28 (1992), 355-361

LEWIS, G.S.; NEWMAN, S.K.:

Changes throughout oestrous cycles of variables that might indicate oestrus in dairy cows. J. Dairy Sci. 67 (1984), 146-152

LINZELL, J.L.; PEAKER, M.:

Efficiancy of the measurement of the electrical conductivity of milk for the detection of subclinical mastitis in cows: detection of infected cows at a single visit. Br. Vet. J. 131 (1975), 447-460

MAATJE, K.; LOEFFLER, S.H.; ENGEL, B.:

Predicting optimal time of insemination in cows that show visual signs of oestrus by estimating onset of oestrus with pedometer. J. Dairy Sci. 80 (1997), 1098-1105

MACK, G.:

Wirtschaftlichkeit des züchterischen Fortschritts in Milchviehherden - Gesamtbetriebliche Analyse mit Hilfe eines simultan-dynamischen linearen Planungsansatzes. University of Hohenheim, Germany, Ph.D. Thesis, 1996

MAKRIDAKIS, S.; WHEELWRIGHT, S.C.:

Forecasting methods and application. The Wiley/Hamilton series in management and administration, John Wiley \& Sons, New York. 1978

MATLAB:

2000. The MathWorks, Inc., Version 6.0.0.88.

MELE, M.; SECCHIARI, P.; SERRA, A.; FERRUZZI, G.; PAOLETTI, F.; BIAGIONI, M.:

Application of the 'tracking signal' method to the monitoring of udder health and oestrus in dairy cows. Livest. Prod. Sci. 72 (2001), 279-284

MOTTRAM, T.:

Automatic monitoring of the health and metabolic status of dairy cows. Livest. Prod. Sci. 48 (1997), 209-217

MOTTRAM, T.; VELASCO-GARCIA, M.; HART, J.; PEMBERTON, R.:

The optimum time of sampling during milking with a biosensor based system for automatic ovulation prediction of dairy cows. ASAE Meeting Presentation, International Summer Meeting, Convention Center Sacramento, California, 30. July-1.August, 2001, Paper No. 943027, 1-12. 2001 
ROTH, H.:

Automatisches Erkennen des Konzeptionsoptimums bei Milchkühen mit Hilfe rechnergestützter Systeme zur Herdenüberwachung. Landbauforschung Völkenrode, Sonderheft 83, 1987

SAMBRAUS, H.H.:

Nutztierethologie. Verlag Paul Parey, Berlin und Hamburg. 1978

SAS:

1998. SAS/STAT User's Guide (Release 6.03). SAS Institute, Cary, NC, USA.

SCHOFIELD, S.A.:

Oestrus detection methods and oestrus behaviour of dairy cows in different environments. Dissertation Abstracts International B, Science and Engineering, 49 (1989) 7, 2432

SECCHIARI, P.; ROMAGNOLI, S.; MELE, M.; FERRAMOSCA, R.:

Use of a computerised pedometer for heat detection in dairy cows. Zoot. Nutr. Anim. 24 (1998), 119124

SECCHIARI, P.; MELE, M.; LEOTTA, R.:

An exponential smoothing model in time series analysis of milk electrical conductivity data for the clinical mastitis detection. 50 $0^{\text {th }}$ Anual Meeting of the European Association of Animal Production Zurich, Switzerland 23-26 August 1999

SENGER, P.L.:

The oestrus detection problem: new concepts, technologies and possibilities. J. Dairy Sci. 77 (1994), 2745-2753

STUMPENHAUSEN, J.:

Tieraktivitätsmessung mit Pedometern zur Verbesserung des Gesundheits- und Fruchtbarkeitsmanagements in Milchviehherden. In: Bau, Technik und Umwelt in der landwirtschaftlichen Nutztierhaltung, Beiträge zur 5. Internationalen Tagung in Hohenheim, 6.-7. März 2001, Hrsg.: Institut für Agrartechnik der University of Hohenheim. Germany. pp. 272-276, 2001

VAN ASSELDONK, M.A.P.M.; HUIRNE, R.B.M.; DIJHUIZEN, A.A.:

Quantifying characteristics of information-technology applications based on expert knowledge for detection of oestrus and mastitis in dairy cows. Prev. Vet. Med. 36 (1998), 273-286.

WENDL, G.; KLINDTWORTH, K.; WAGNER, M.:

Einsatz von Aktivitätssensoren und injizierbaren Transpondern mit integriertem Temperatursensor in der Milchviehhaltung. $46^{\text {th }}$ Annual Meeting of the European Association of Animal Production Prague, Czech Republic, 4.-7. September 1995. Paper No. C 4.6. 1995

WENDL, G.; KLINDTWORTH, K.:

Einsatz von Elektronischen Schrittzählern (Pedometer) zur Brunsterkennung bei Milchkühen. In: Bau, Technik und Umwelt in der landwirtschaftlichen Nutztierhaltung, Beiträge zur 3. Internationalen Tagung in Kiel, 11.-12. März 1997, Hrsg.: Institut für Landwirtschaftliche Verfahrenstechnik der Christian-Albrechts-Universität Kiel, Germany. pp. 335-343, 1997

XU, Z.Z.; MC KNIGHT, D.J.; VISHWANATH, R.; PITT, C.J.; BURTON, L.J.:

Oestrus detection using radiotelemetry or visual observation and tail painting for dairy cows on pasture. J. Dairy Sci. 81 (1998), 2890-2896

YANG, Y.:

Rechnergestützte Östrusüberwachung bei Milchkühen unter Anwendung der Fuzzy Logic Methode. University of Munich, Germany, Ph.D. Thesis, 1998

Received: 2002-11-11

Accepted: 2003-02-11

Author`s address

Dr. REGINA FIRK, Dr. ECKHARD STAMER,

Dr. WOLFGANG JUNGE, Prof. Dr. habil. JOACHIM KRIETER

Institut für Tierzucht und Tierhaltung der Christian-Albrechts-Universität zu Kiel

Olshausenstr. 40

D-24098 Kiel

Germany 